\title{
THE FUSION OF THE LOVE VIEW OF CONTEMPORARY COLLEGE STUDENTS AND FROMM'S THOUGHT
}

\author{
Liu Chuanlei' ${ }^{1}$ Yin JiXing ${ }^{1}$, Ma LinCong ${ }^{2}$, Han Yuan Fei ${ }^{1}$, Wu Guojun ${ }^{1}$ \\ ${ }^{1}$ Heilongjiang Bayi Agricultural University, Heilongjiang Daqing 163319, China \\ ${ }^{2}$ Hebei transportation vocational and technical college, Hebei Shijiazhuang,150081, China \\ *Corresponding Author Email: 312332575@qq.com
}

This is an open access article distributed under the Creative Commons Attribution License, which permits unrestricted use, distribution, and reproduction in any medium, provided the original work is properly cited.

\section{ARTICLE DETAILS}

\section{Article History:}

Received 26 April 2018 Accepted 27 May 2018 Available online 1 January 2018

\section{ABSTRACT}

Good romantic love is what every college student expects, but do they really know love at this stage? In today's rapid development of the productive forces, science and technology changes with each passing day, the social material wealth increase, especially in this age of college students, their infection by today's society on one hand, have affected by the consciousness of scholarly campus academic atmosphere. They yearn for a romantic love that is imagined, on the other hand, from the society, the reality of the family and the development of their love on the other hand. Airy, Fromm's, 20th century western famous sociologist, philosopher and psychoanalyst, through analyzing the western capitalist society's love with the human situation are studied, and on the basis of inheritance of Marxist ethics love, with the development of Freud's theory of love, on the basis of social critical theory of Frankfurt thoughts formed a unique love education idea. He believes that love has nothing to do with the maturity of the individual, but to put aside the feelings of mind and body. If you don't try to develop your own personality and tend to create a tendency to create, then every attempt to love will fail. If you are not able to love others, if you are not brave enough to love others sincerely, then your life will never be satisfied. Fromm further believes that love is an art that requires those who want to master art, master knowledge and work hard. Here, love is not only about the narrow love of men and women, but also through certain skills. Love is the overall expression of individuality and the ability to develop love. It is necessary to strive to develop and perfect one's personality and move towards a good goal. We focus on college students' love view and love development theory, further explore the study of contemporary college students' love, and enter the world of contemporary college students' love. focusing on college students' love view and love development theory, further exploring the study of contemporary college students' love, thus entering the world of contemporary college students' love. In this paper, the author points out the true meaning of love: love is a positive concern, giving is a positive love, respect is the core of love, and needs to know love in practice.

\section{KEYWORDS}

college students, Love, Fromm, The fusion.

\section{CONTEMPORARY COLLEGE STUDENTS WILL CONSIDER LOVE AN ART}

\subsection{The love opinion of contemporary college students}

Contemporary college students pursue love. They never get tired of boring love songs, but they don't think people can learn love. They hold this strange attitude for a reason, and these reasons is separately or jointly strengthened their attitude, they are not aware that their fundamental questions about the ability to love. Instead, they think that love can be loved, so they take all kinds of different ways. Man as much as possible to gain fame and power, women with their bodies in increasing your charm, get love, to make themselves in many ways, to take the same way, in order to win the opposite sex appeal.

Love is a "burning friendship" based on tolerance, love and communication. Landers' description of love, is it different from your love? What's the difference between romantic love and infatuation? According to psychologist Robert Sternberg, different kinds of love can be made up of three different components: intimacy, passion and loyalty. If love is a triangle, then these three components are the three sides of this triangle. We know that the change in the length of the three sides of a triangle also changes the shape and size of the entire triangle. The love triangle can also be understood in this way, the change of the three elements of intimacy, passion and loyalty can also produce different types of love. The missing love type is "loveless" and high degree of intimacy. When passion and loyalty are very low, that kind of love is just like. Some people's love, lack of intimacy or loyalty, but have a strong passion, that kind of person's love is called infatuation. Some people's love, have loyalty, but have no intimacy or passion, that kind of love type, is empty love.

The problem of love is an object problem, not necessarily a problem of ability. People will think that love itself is very simple, the difficulty lies in finding the object of love, and the root cause of these is the development of modern society.

\subsection{Love in a social way}

In many traditional cultures, love is not spontaneous and ultimately leads to a personal marriage experience. In the 19th century, when the Victorian summoned, marriage is mainly composed of men and women family members, introduce or treaty decided to pay attention to the wedding parties at the time, for love, people think that marriage will appear naturally. In the 20th century, the concept of romantic love in the western world generally recognized that this new form of love would certainly greatly enhance the importance of the object of love, rather than the meaning of love itself.

We can make a deal, the happiness of modern people is to enjoy window (namely window), use cash or instalments to buy what he can do. A person "attractive" will be a feature of interest in the population market. Fashion, health, and his spirit will be his charm, such as in the $20 \mathrm{~s}$ of the 20th century, smoking, drinking, elusive and sexy woman was seen as a charm, today's women can do household chores, be modest and prudent. Men 
who are full of career anxiety and ambition are attractive, but now they are concerned that good people are more popular. In the final analysis, the generation of love is based on the balance and exchange value of each other. If you want to make a deal, it is considered from the perspective of social values, the value of the opening is not worth our pursuit, but also considering our strength and potential, in addition the deal cannot be regarded as to buy land, another potential also plays an important role in the future. In a word, the love relationship between people also follows the same basic principles as commodity management and labor market.

The patterns of love vary from culture to culture. It is widely believed that people can only consider marriage if they love each other. However, different social cultures have different views on love. If you are an ancient Greeks, you fall in love with a person love to crazy time, people will think you are a madman, and this delusion love and marriage, the family had nothing to do, at the time of the ancient Greeks advocating Plato type love, such as between the two men with no sexual love. If you are an ancient Egyptian nobleman, you can only choose from your own kin. If you were the ancient Romans, you will find that people generally think that marriage is to have children, to get married to and the rich and powerful ally, marry is for and that the nobles built up blood ties. If you grew up in the 12th century Europe, and you are a straight, so worth you fortunately, people will feel that your love will be as beautiful as "court" love, love need to court love as a kind of noble spiritual pursuit, dedicated to dame cobest, this love is very ideal, is also very elegant. The hero of court love is normal, but the heroine is a married woman, because in medieval Europe, no one expected marriage romance; On the contrary, marriage and politics are regarded as very serious subjects, and the act of intense sexual desire for the opposite sex is also stigmatized as the gateway to hell.

\subsection{The confusion of college students' love opinions}

Modern college students are hard to find out "in love" and "everlasting love" the difference, the two of them they were separated by suddenly in a flash to decide to dismantle the high wall, together, they combine the moment will become the most happiness, the most exciting experience. This sudden between men and women, a miracle is likely to happen, intimacy is often closely related to same-sex attraction and sexual union or is caused by, but love is the essence of this type is impossible to lasting, although the two cooked depending on each other, but they trust will be more and more lost its miraculous characteristics, so that hostility, disappointment and boring erase all the charm of life, because only the objective understanding a person, can know his true nature in love.

If you think that love is an art, students will first learn to love, you have to be like other arts, such as music, painting, the same action or medical art and technology, it is only through long-term practice, to integrate theoretical knowledge and practical speech into a consistent inspiration, that master the art of the soul, become a master. College students, on the one hand, yearn for love; on the other hand, they devote almost all their energies to achieving the above purposes, such as fame and fortune, and seldom to learn the art.

\section{THE ESSENCE OF LOVE}

\subsection{Love is a positive concern}

True love interest, on the other hand, but too many college students think that love is a way to get rid of the lonely life, and they produce loneliness makes them in college in the university life, a feeling of fear. In fact, loneliness is the root of every fear. Therefore, college students need to overcome loneliness and get rid of solitary confinement. They pursue love, regardless of a little future, only indulge in the two together, to get rid of the loneliness of college life. Find your partner and take a walk around the campus. Those who don't find a partner are very jealous and are actively looking for their partner. This kind of love makes them feel better, but they ignore the basic love and the true meaning of love.

True love evokes a certain energy of things that will awaken a certain energy and a happy heart. Love is also a positive concern for the growth of life and the things we love. If this lack of positive care, then this is only an emotion, not love, at this stage, college life has not yet come, more time is to develop themselves, enrich themselves. If he is not responsible for his own life, how can he be responsible for his love? It's like a woman telling us she loves flowers, but we find she forgot to water the flowers, and we don't believe what she says. Likewise, for ourselves, for love, we need our positive intentions.

\subsection{Giving is positive love}

Giving the true meaning of love is not hyperbole, giving is the highest potential performance. Love is positive, not negative. Man is something inside, not captured. In general, you can express it with another argument, love is the first to give it.
I once saw a tearful classmate on campus and asked for the reason out of concern and sympathy. The girl he had been after had not promised him, and even fell in love with other boys, and complained to me that he had paid a lot. Admittedly, the boy did give the love he longed for, but he took it as a negative emotion, a captive emotion. The true meaning of giving is not how much to give, but the kind of care that comes from the heart, a kind of giving that cherishes one's life, that is, the two together. True giving is what you give to your life.

The other thing about the boy is that he doesn't really know each other, and he knows each other. Blindly pay blindly, only to end up sad. Only by knowing each other and understanding each other can we respect each other. If not based on understanding, care and responsibility are blind. This is not helpful if you don't get to know each other from a caring perspective. There are many ways to understand, and to be a part of love is to know the inside of things, not to be content with a little knowledge. You can only get to know each other better if you look at others with the eyes of others and take your own interest in the second place.

\subsection{Respect is the heart of love}

Love, as an advanced form of human emotion, is the most complex and subtle. Psychology in the definition of it is that love is a pair of men and women based on certain objective material base and the common ideal of life, in their respective formed inside the most sincere admiration for each other, and eager to each other as a partner of the most strong, stable and specific feelings.

Old friend remembers university feifei and window talked about in the university three years in love, the first and second years, window every morning to feifei texting, told her to get up, before he goes to bed at night, good night, send a short channel usually have nothing is three five report for instructions. At that time, feifei felt very happy and thought that wen tao was the "Mr.Right" in his life. In senior year, the window began to practice, a day too tired to fall asleep, and feifei internship is very easy, the two separate two places, she waits for window messages every day, but the message is less and less. Feifei is very upset, often text message to send in the past to complain, you do not love me, have changed heart? Why is it so far apart that texting is becoming less and less? She felt that if she could do it for two years, she could do it now. But wen tao thinks, two years passed, love also should enter the flat period, now everyone should strive for the ideal and future life. You can't buy bread, or love. And Fifi should learn to take care of herself, always like a small child, she will feel tired. He felt that Fifi did not understand himself and understood how difficult it was.

In fact, college students are now more common in college campuses. But many students can't rationally treat love, do not know how to keep the love for a long time, the so-called "fall in love easily, get along with difficult," love is not only the secretion of hormones, is a kind of ability, psychologist flom said: "love is an active ability; The ability to break through the walls of any other company; An ability to combine people with others. Love overcomes loneliness and separateness, but he allows him to be himself, allowing him to maintain his integrity" [1]. This ability is not inborn. If you want to keep your love long, you need to learn to deal with the relationship between love and study, love and others, love and personal development.

With the development of body and mind, college students will gradually understand the meaning of love in the coming love life. As Marx said in his philosophy manuscript, "if you're in love, but did not arouse the love of others, that is your love as a kind of love can't make love each other, if is a love of people, you can't put themselves into a loved person, then your love is weak, is a kind of misfortune." [2].

To pursue true love, he should share his happiness, interest, understanding, knowledge, humor and sadness with others. In short, all he was alive. Through him, he enriched others and raised his awareness of life. He also raised his awareness of life. In this way, the energetic love will make him feel happier.

\section{THE PRACTICE OF LOVE, LOVE IN PRACTICE}

\subsection{True love is a prerequisite for practice}

Love is a person's experience, and everyone can only get it by himself. Therefore, the practice of discussing love can only be the premise of discussing practice, which is the initial step of practice. Any art needs to have some basic things, such as woodworking art, medical art and love art. The first requirement is discipline, the necessary condition is concentration, and then patience and great interest. A strict pursuit of love 
life, focusing on love, staying awake, and learning patience while practicing concentration. Interest is the best teacher. Looking for positive love also enhances our understanding of the art of love. These are the conditions for the pursuit of the art of love, and the special conditions that Fromm believes are crucial to mastering the art of love. According to his description of the nature of love, the main condition for the ability to acquire love is to overcome narcissism, rather than to think that better performance will lead to more happiness and romantic love. All external factors, such as honor, status, family condition, etc., have nothing to do with love. Love is an inner personality, love is not superficial, but is a kind of nutrition from the heart. In the university life, some boys think you good grades, organization ability is strong, so they must find the capital of love, the girl will be because of who I am is a good boy proudly showing off. It is the art of leaving love and not even respecting it. Their narcissism can make them feel lonely, even if they can catch each other's hands. Only through true love can they get rid of the loneliness caused by narcissism and begin to experience the unity of caring for others and feel the power of love.

\subsection{Romance and love should also be a prerequisite for marriage}

Once upon a time, marriage and love has little to do, if really have such a man in the world, the person's body has everything you look forward to good quality, is the only make you feel sorry, you haven't fall in love with this person, then you will choose to marry the man? Most people the answer is no, in fact, as early as the end of the 20th century in the United States, young people would believe that romantic love is the necessary condition of marriage under the influence of western culture, it is widely accepted that young love and romance should also is a prerequisite for marriage. However, when you look back on human history of marriage, you will find, romance, love, these two things, and marriage is not much, will people in order to enhance the level of social status or improve your life and get married, even in North America, people also began to feel that in recent years, the love is an indispensable part of marriage. In 1967, 67 percent of American men were willing to marry women who did not have a romantic relationship with themselves but were clearly superior to their own. For now, most people would reject a marriage without love. In a sense, we are making bold attempts at the moment, after all, few people think that love is an essential part of marriage. Nowadays, people all over the world are pursuing passion and romance, but there are also many places where love is not a prerequisite for marriage. In 2008, Hatfield and pull Posen, according to a study of the north American culture already believe, love is combined with the premise of the people, and people will love in marriage status, to an unprecedented height. Nowadays, there are a variety of love in the world pattern, and different types of love, but, if the close relationship between two people did not have the romance and passion, originally for romance and passion together, two people close relationship are also facing serious test. Are the marriages of romance and passion doomed to disappointment?

When we are uprooted in an unfamiliar environment, everyone is more or less uncomfortable. But a person's potential is huge, after a period of selfregulation, can be adjusted slowly. However, many students do not give themselves the opportunity to exercise. Once they are empty and lonely, they can't stand the loneliness and immediately try to fill it with love. When your life needs to be filled with love, learning, ability, and networking are all on the side. So, what do you get when you graduate? Learning is bad, ability is not, network is not enough, how to find oneself satisfactory job, once love also has no, then you will have nothing. In fact, it is very important to learn to be cautious and self-disciplined in college. People often say that now, if a person alone, cannot stay, will not turn on the TV, just will open the computer, if without these, can somehow produce a kind of fear, you are also like this? If so, your heart isn't rich enough. Students, when we have time to waste, don't learn to others blindly to fall in love, to play online games, and should hold out your own inner standards, learn to enrich their own life, life can be is another landscape.

\subsection{Know love in practice}

In a series of survey of college love, many college students have many questions about love in college. In the face of some questions raised by some college students to make some comments, specific to carry on the understanding of the university love practice, so as to understand the love in the university.

Some students do not know the difference between like and love, do not know whether they really like the other party, or is the result of the ambiguous atmosphere influence. Usually need to spend a little time, that is, find themselves appreciate $\mathrm{Ta}$, want to close to the Ta, when his later found each other's face, still can maintain this relationship, it is really like them. But if you think "I'm stupid! It was like a period of idolatry. So, idols are always mysterious. It can also be judged by the way you look, the way you look, the way you look, or you feel guilty. Learn some nonverbal communication also is very good. College students are very concerned about how to make love permanent, but they can't find the answer in practice. It doesn't exist, right? How can long lasting love exist? You don't have to go for it. All relationships end, only in natural and artificial ways. The natural way is to die, the so-called artificial way is to break up. So, in order to avoid breaking up, we should learn to maintain.

Once in a speech, some students asked the teacher what you think of the true love movement. The true love movement is the church wants you not to have sex before marriage. Is it true love? This is not to have sex before marriage! Is true love = sexual behavior? There is no relationship between the two. So, my definition of true love is that you don't want to think about how others define, sometimes is very personal to fall in love, you and she can be, and what other people think is the attitude of others. The lover may be able to manifest the glory of human nature, not just sex. It is wonderful why we are willing to sacrifice and sacrifice for those who are not related [3].

In western thinking, there is always "love can solve all" thinking, but the Chinese have not [4]. Romeo and Juliet are dead, but the two families are together; But liang shanbo and zhu yingtai became butterflies, and the two families were separated. Dou e is the cause of the warming of the earth, so not everything can be solved by love [5].

As from concluded, childlike love follows the following principles: "I love, because I am loved." The principle of mature love is: "I am loved, because I love." Immature, childish love is: "I love you, because I need you." And mature love is: "I need you, because I love you."

Love needs to be practiced, it needs to master the theory of the art of love to follow the theory to practice, so that in the university can get a permanent and sincere love.

Analyzing the essence of love is to make sure that contemporary college students seldom experience love, but at the same time, they should ponder the personal and social reasons for this phenomenon. It is believed that love can develop from a sporadic phenomenon to a common phenomenon [6]. Hope college students understand love, respect love, explore love, and thus practice love.

\section{REFERENCES}

[1] Fromm. 2008. The art of love. Shanghai: Shanghai translation publishing house, 17-18.

[2] Marx. 1979. The economic and philosophical manuscripts of 1844. Beijing: people's publishing house, 108-109.

[3] Xia X.J. 2017. Sociological dynamic brain. Taiwan: Taiwan political university.

[4] Azizul Azhar R., Shahreen K., Mohd Farhan M.F., Hairulnizam M. 2017. Teaching Performance Evaluation Framework: An Analytic Hierarchy Process Approach. Acta Informatica Malaysia, 1(1), 01-06.

[5] Sara H. 2018. Knowledge Grid Model in Facilitating Knowledge Sharing Among Big Data Community. Acta Informatica Malaysia, 2(1), 17-18.

[6] Li Y.J., Peng R.Q. 2017. Research on output value and social responsibility of Chinese pharmaceutical industry based on multivariate statistics. Malaysian E Commerce Journal, 1(1), 09-10.

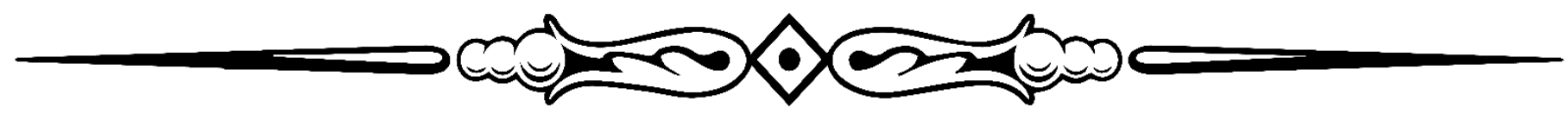

